удК 343.1

DOI https://doi.org/10.32837/pyuv.v0i3(32).612

\author{
А. В. Ратнова \\ orcid.org/0000-0002-5447-7256 \\ ад’юнкт кафедри кримінального процесу та криміналістики \\ факультету № 1 \\ Інституту з підготовки фахівців для підрозділів Національної поліиї \\ Львівського державного університету внутрішніх справ
}

\title{
ПРОВЕДЕННЯ ОГЛЯДУ ОБЛІКОВОГО ЗАПИСУ КОРИСТУВАЧА В СОЦІАЛЬНІЙ МЕРЕЖІ ПІД ЧАС ДОСУДОВОГО РОЗСЛІДУВАННЯ КРИМІНАЛЬНОГО ПРОВАДЖЕННЯ
}

Постановка проблеми. Соціальні мережі один 3 найпростіших способів розміщення та отримання інформації. Користувачі соцмереж активно поширюють свої думки, діляться життевими подіями, фото, відео, коментують ситуації, що відбуваються з ними чи у світі. Таким чином, у соціальних мережах можуть міститись відомості, які встановлюють наявність чи відсутність фактів та обставин, що мають значення для кримінального провадження та підлягають доказуванню. Однак відсутній єдиний підхід у отриманні відомостей зі сторінок соціальних мереж, їх фіксації та зберігання.

Порушення основних вимог КПК України щодо збирання доказів може призвести до визнання таких доказів недопустимими, а відповідно, і до втрати доказів стороною обвинувачення.

Аналіз останніх досліджень. Окремі питання огляду електронних документів уже були предметом розгляду таких науковців, як О.В. Коваленко, О.В. Малахова, Є.С. Хижняк. Однак у цих дослідженнях поверхнево розглянуто огляд вебсторінок. Водночас немає публікацій щодо особливостей огляду облікового запису у соціальних мережах, аналізу судової практики у такому напрямі.

Метою нашого дослідження є аналіз наукових публікацій, судових рішень, пов'язаних з оглядом особистих сторінок у соціальних мережах та використанням їх як доказу під час досудового розслідування.

Виклад основного матеріалу. Є.С. Хижняк зазначає, що Інтернет, соціальні мережі, електронне листування останнім часом стають одним з найголовніших джерел інформації, що має значення для розслідування злочинів [13, с. 83].

Натепер велика кількість користувачів соціальних мереж ведуть активне соціальне життя у мережі. Інформація, отримана з облікового запису користувача, може бути корисною для встановлення кола осіб, з якими знайома особа, отримання фото особи, вивчення особистих якостей, захоплень тощо. Ці відомості згодом можна використати для складення версій і плану розслідування, подальшого проведення слідчих (розшукових) дій, негласних слідчих (розшукових) дій, оперативно-розшукової діяльності.

За допомогою листування у соціальних мережах користувачі можуть домовлятися про спільне скоєння певного злочину, уточнювати деталі, розробляти план його скоєння та приховування. Також листування може бути підтвердженням між особами конфліктних відносин, вислову образ, шантажу, погроз, приниження честі та гідності.

Основною метою документа є збереження та передача інформації. Оскільки у КПК України визначено, що документ, а у певних випадках електронний документ є джерелом доказу, то, відповідно, фактичні дані у цих документах (інформація) і є доказом. «Електронний документ» - це інформація, яка міститься в електронній формі та може бути використана як доказ факту чи обставин, що встановлюються під час кримінального провадження [7, с. 238].

Отже, особиста сторінка у соціальній мережі (або аккаунт, обліковий запис) може бути електронним документом, а отже, і доказом у кримінальному провадженні.

Однак технічна сторона фіксування даних соціальних мереж потребує вдосконалення [9, с. 135].

Для отримання (фіксації) електронного документа необхідно провести відповідну слідчу (розшукову) дію, а саме огляд. У КПК України відсутнє право огляду доказів, у тому числі електронного документа стороною захисту, адже ст. 237 КПК України зазначає вичерпний перелік осіб, які можуть проводити огляд. Тому сторона захисту має право надати електронний документ слідчому чи прокурору для огляду та долучення його до матеріалів кримінального провадження [6, с. 37]. Вважаємо, що оперативний працівник за дорученням слідчого теж може оглянути сторінку у соціальній мережі.

Процес огляду електронних документів загалом відповідає загальноприйнятому алгоритму дій, які вчиняються слідчим під час огляду звичайних документів. Такий комплекс дій повинен складатися з такого: 1) пошук і виявлення документів; 2) візуальний огляд зовнішнього стану без зміни умов сприйняття; 3) фіксація за допомогою 
фотозйомки; 4) фіксація в протоколі відповідної слідчої дії (фіксуються всі дії посадових осіб, стан документа і виявлені сліди); 5) виявлення слідів рук (на фізичному носії електронного документа); 6) виявлення слідів зміни первісного змісту; 7) підготовка до упаковки; 8) упаковка [2, с. 129].

Однак огляд облікового запису у соціальній мережі має свої особливості. Деякі сторінки можуть бути у вільному доступі, а інші - приховані від користувачів. У зв'язку з цим огляд сторінки у соціальних мережах залежно від ступеня доступу до облікового запису може проводитись:

1) без відома особи - власника облікового запису із загальнодоступного ресурсу;

2) з добровільним наданням доступу володільцем до персональної інформації облікового запису, листування тощо;

3) отримання доступу до персональної інформації облікового запису, листування на підставі рішення суду.

Слідчий може проводити огляд загальнодоступної персональної сторінки особи у соціальній мережі без її відома. Зазвичай такий огляд проводиться для збирання відомостей, які з дозволу власника сторінки є оприлюдненими. До таких відомостей можуть бути віднесені фото власника облікового запису, дата народження, місце проживання, місце роботи, публікації, коментарі до цих публікацій власника та інших осіб. Особисте листування власника облікового запису у такий спосіб огляду отримати неможливо.

Огляд загальнодоступного облікового запису можна здійснювати: 1) без входу в обліковий запис соціальної мережі (якщо мережа надає можливість оглянути сторінку); 2) з особистої сторінки працівника; 3) з новоствореного облікового запису.

На думку О.В. Малахової, отримання з Інтернет фактичних даних, доступ до яких необмежений, не може здійснюватися шляхом провадження такої дії, як зняття інформації з електронних інформаційних систем, оскільки порядок виявлення та фіксації таких відомостей не пов'язаний 3 подоланням захисту інформації від втручання інших осіб, а тому не відповідає суті негласної слідчої (розшукової) дії [5, с. 66].

Наприклад, під час досудового розслідування кримінального провадження проводився огляд загальнодоступних відомостей: проведено порівняння ознак зовнішності обличчя особи чоловічої статі, яке зображено у кадрі, із зображеннями на фотознімку копії паспорта на гр. Д та фотознімку у протоколі огляду акаунту в соціальній мережі «Вконтакте» та виявлено їх схожість; огляд додатка до акта огляду публічно доступного акаунту «гр. Ч» у соціальній мережі «ВКонтакте», згідно 3 яким видається, що гр. Ч сам робив публікації на своїй сторінці, яку відвідували інші особи, деякі з них робили позначки «мені подобається».
Під час дачі показів у суді спеціаліст, який був залучений до огляду сторінки «ВКонтакте», пояснив, що під час розміщення на сторінках у соціальній мережі «ВКонтакте» інформації над указаним розміщенням автоматично зазначається ім'я користувача сторінки (акаунту). Також під розміщеною інформацією автоматично зазначається дата та час її розміщення, що відповідає реальному часу. Свідок зазначив, що під час досудового розслідування йому надавались роздруківки файлів зі збереженою інформацією зі сторінки у соціальній мережі «Вконтакте» користувача «гр. К», ознайомившись 3 якими він указав, що всі розміщення, зафіксовані у вказаних роздруківках, здійснено користувачем мережі «Вконтакте» під ім'ям «гр. К». Активність на сторінці була досить велика, були дописи, пости, репости. Зокрема, на сторінці було зображення прапора України, опущеного в унітаз [3].

Також під час дослідження сторінки гр. Т у соціальній мережі «Вконтакте» стало відомо, що останній вказав місце роботи «Новороссия TB, Народный телеканал, Донецьк, Технічний директор", а обвинувачений перебуває у нього в друзях [3].

Отже, якщо відомості, які можуть мати доказове значення, перебувають у відкритому доступі, то вони можуть бути оглянуті без надання дозволу особи чи рішення суду.

Огляд особистої сторінки у соціальній мережі з добровільним наданням її власника доступу до персональної інформації та листування може бути проведений з метою підтвердження чи спростування наявної інформації. Такий огляд проводиться у разі, якщо володілець облікового запису добровільно надає логін та пароль облікового запису або мобільний телефон чи інший технічний пристрій з авторизованим обліковим записом. Наприклад, під час огляду листування у соціальній мережі можна перевірити факт висловлення образ, погроз, шантажу; схиляння до вчинення чи приховування злочинів; встановити мотив i мету злочину; факт отримання чи пересилання коштів тощо.

Листування може підтвердити адміністрування радикальної спільноти, участь у ній уже відомих співучасників та встановити осіб, які також причетні до скоєння таких злочинів. Приватна бесіда між співучасниками злочину дає можливість дізнатись мотив, мету, роль учасників злочину та іншу інформацію, яка є предметом доказування. Зокрема, у справі № 461/485/17 Колегія суддів судової палати 3 розгляду кримінальних справ Львівського апеляційного суду зазначила, що у ході судового розгляду знайшло своє підтвердження обвинувачення гр. Ж у частині наявності змови про вчинення дій з метою насильницького захоплення державної влади. Окрім визнання 
обставин скоєння злочину обвинуваченими, на наявність в їхніх діях ознак складу злочину вказували предмети, які були вилучені в останніх, їхнє особисте листування в соціальній мережі, документи з розподілом ролей учасників змови, які зберігались на їхніх персональних комп'ютерах та носіях інформації тощо [11].

Якщо отримати кримінально значиму інформацію неможливо загальнодоступним способом, а особа не надає дозволу на отримання такої інформації добровільно, слідчий повинен звернутись 3 відповідним клопотанням до слідчого судді.

Ані ухвала про обшук, ані ухвала про арешт мобільного телефону не надає автоматичний дозвіл на доступ до наявної в ньому інформації, оскільки у жодному із зазначених рішень не досліджується питання щодо законності та необхідності таких дій. Так, слід зазначити, що згідно з практикою ЄСПЛ надто широке тлумачення змісту ухвал, винесених слідчим суддею, зокрема вчинення дій, що не були чітко передбачені такими ухвалами, є окремою підставою для констатації ЄСПЛ порушення статті 8 Конвенції (див. рішення у справі "Hambardzumyan v. Armenia", заява № 43478/11, пп. 65-66). 3 тих же міркувань немає жодного значення, чи доступ до інформації на телефоні захищено паролем, чи ні. Перегляд, копіювання та використання такої інформації є втручанням у право на повагу до приватного життя. Тому єдино можливим способом використання наявної на вилученому телефоні інформації є отримання з цією метою окремої ухвали суду, в якій буде чітко вказано, доступ до якої інформації надається. Відсутність такої ухвали автоматично тягне за собою порушення прав, гарантованих статтею 8 Конвенції, а отже, згідно зі ст. 87 КПК України, недопустимість як доказу вилученої з телефону інформації (документів) [1].

Наприклад, ухвалою Жовтневого районного суду м. Дніпропетровська від 26.06.2019 року суд надав слідчому тимчасовий доступ до речей, які містять охоронювану законом таємницю (відомості про особисте листування та інші записи особистого характеру), які зберігаються в належному гр. П. мобільному телефоні, вилученому в ході обшуку клубу «Потьомкін», з можливістю ознайомлення $з$ ними та зняти їх копії, а саме: листування 3 використанням електронної пошти, змісту спілкування (листування) в програмному забезпеченні, що встановлене в мобільному телефоні та забезпечувало можливість передачі даних (Viber, Telegram, WhatsApp, Gmail, Google, Фото), стосуються зв'язків та/або листування між власником клубу та іншими особами, які відвідували клуб «Потьомкін» [10].

Слідчий також може звернутись до суду з клопотанням про проведення обшуку з можливістю отримання доступу до інформації, яка міститься у мобільних телефонах, комп'ютерах чи інших технічних пристроях. Наприклад, в ухвалі Солом'янського районного суду м. Києва від 19.07.2019 року у справі №760/16979/19 суд зазначив, що згідно з ч. 7 ст. 236 КПК України під час обшуку слідчий, прокурор має право проводити вимірювання, фотографування, звуко- чи відеозапис, складати плани і схеми, виготовляти графічні зображення обшуканого житла чи іншого володіння особи чи окремих речей, виготовляти відбитки та зліпки, оглядати і вилучати документи, тимчасово вилучати речі, які мають значення для кримінального провадження. Дозвіл на проведення обшуку отримано з метою відшукання та вилучення предметів, документів, пристроїв, які містять інформацію про постачання на користь OSUNA Holding LLP та GLD Trade Holding LLP деревини, в тому числі мобільних телефонів, мобільних терміналів систем (у разі неможливості копіювання, якщо доступ до них обмежується їх власником, володільцем або утримувачем), що було у зазначено в ухвалі. Крім того, власник мобільного телефону добровільно надав його детективам для копіювання 3 нього інформації [12].

Особливості складення протоколу огляду облікового запису користувача у соціальній мережі.

Є.С. Хижняк звертає увагу на те, що слідчий огляд електронних документів здійснюється 3 урахуванням певних особливостей об'єкта дослідження, що впливає як на сам процес дослідження, так і на спосіб процесуального закріплення отриманих результатів [13, с. 82].

У вступній частину протоколу огляду особистої сторінки у соціальній мережі слід зазначити місце, дату і час проведення огляду, особу, яка проводить процесуальну дію (прізвище, ім'я, по батькові, посада); всіх осіб, які присутні під час проведення процесуальної дії, інформацію про осіб, які беруть участь у процесуальній дії; технічні засоби фіксації, характеристики технічних засобів фіксації та носіїв інформації, які застосовуються у разі проведення процесуальної дії, умови та порядок їх використання.

Для проведення огляду сторінки у соціальній мережі доцільно залучати спеціаліста, який під час огляду може звернути увагу на важливі деталі та допоможе підготувати додатки до протоколу огляду, скопіювати обліковий запис на носій інформації.

А.В. Коваленко вважає за доцільне у протоколі огляду зазначити серійний номер службового комп'ютера, назву та версію операційної системи, якою керується цей комп'ютер, назву та версію програми-браузера, за допомогою якої здійснюється доступ до Інтернету. Вебсторінка має бути масштабована у браузері на повний розмip (100\%). У браузері мають бути відключені всі додатки та надбудови, що можуть змінити вигляд вебсторінки, яка оглядається [4, с. 187-188]. 
На нашу думку, огляд не обов'язково проводити з комп'ютера, оскільки практично всі соціальні мережі мають власні мобільні додатки, які зручніші у користуванні. Якщо особа надає слідчому на огляд свою сторінку у соцмережі на власному мобільному телефоні, то цей огляд слід проводити 3 цього ж мобільного телефону. У такому разі у вступній частині слід зазначити характеристики мобільного телефону та добровільність його надання. Обов'язково слід зазначити: пристрій, з якого здійснювався огляд; інформацію про додаток або браузер, через який здійснювався вхід у обліковий запис. Логін і пароль облікового запису, з якого здійснювався огляд, вказувати непотрібно.

В описовій частині протоколу огляду облікового запису у соціальній мережі обов'язково слід зазначити назву сторінки (ім'я, або нік людини), основні відомості, кількість публікацій, друзів, фото, дату та час отримання повідомлень, їх зміст, обліковий запис, з якого надходили повідомлення, основні персональні дані цього облікового запису та додані ним раніше фотографії тощо. Огляд повинен проводитись за участю власника облікового запису, зі сторінки якого здійснювався огляд. Під час огляду доцільно проводити фотографування екрана (скріншот) чи відеозапис екрана для фіксації послідовності проведених дій самого змісту сторінки, яке потім оформити у вигляді фототаблиці, відеозапису, носія комп'ютерної інформації тощо.

$\mathrm{y}$ протоколі має бути перелічено та коротко описано фото-, відео та аудіофайли, прикріплені до публікації, із зазначенням посилання на кожний із таких файлів у Інтернеті. Значна кількість мультимедійних файлів на сучасних вебсторінках $є$ рекламними оголошеннями, які не стосуються публікації, що вивчається. Такі елементи вебсторінки не потрібно описувати у протоколі огляду електронного документа [4, с. 187-188].

У заключній частині протоколу огляду слід зазначити спосіб ознайомлення учасників зі змістом протоколу, зауваження і доповнення до письмового протоколу з боку учасників процесуальної дії та інформацію про спосіб копіювання/дублювання змісту особистої сторінки на технічний носій, дані та характеристики такого носія, спосіб упакування.

Інформація в Інтернеті є нестійкою та може видозмінюватися користувачами, власниками вебсайту, підлягати впливу комп'ютерних вірусів тощо. Проте сучасні пристрої дають можливість зафіксувати інтернет-сторінку у певний момент часу. Роздруківка інтернет-сторінки полягає у друці за допомогою принтера вмісту вебсайту. Ця дія може здійснюватися за допомогою вікна браузера, у якому ця сторінка відображена, або як роздрукування скріншоту екрана [8, с. 92-93].

Одним із найзручніших способів фіксації електронного документа, розміщеного в Інтернеті, є за- безпечення безперервної відеофіксації екрана під час огляду. Відеозапис зображення екрана мобільного телефону чи іншого пристрою можна здійснити через відповідну програму або така функція може бути передбачена у сучасних версіях операційних систем чи самих пристроїв. Такий відеозапис зафіксує точну дату, час проведення огляду, місцезнаходження електронного документа, його властивості та зміст, що надалі дає можливість ознайомитись з електронним документом повторно.

Висновки. Облікові записи у соціальних мережах є сховищем величезної кількості інформації, яка може бути використана під час досудового розслідування. Обліковий запис у соціальній мережі є нестійкою інформацією та може швидко видозмінюватися, тому правильна фіксація кримінально значимої інформації має велике значення для досягнення мети і завдань кримінального процесу. Під час огляду облікового запису у соціальній мережі обов'язково слід зазначати відомості про технічний пристрій, з якого проводиться огляд, послідовність дій під час огляду: браузер або додаток, з якого здійснюється огляд, зміст інформації, яка оглядається, тощо. Доцільно залучати спеціаліста для виготовлення додатків до протоколу огляду у вигляді фототаблиць, відеозапису та копіювання/дублювання сторінки на окремий технічний носій. Залежно від ступеня доступу до облікового запису у соцмережі огляд може проводитись без відома особи - власника облікового запису із загальнодоступного ресурсу; 3 добровільним наданням доступу володільцем до персональної інформації облікового запису, листування тощо; отримання доступу до персональної інформації облікового запису, листування на підставі рішення суду. Вироблення єдиної практики огляду облікових записів у соціальних мережах з дотриманням основних вимог КПК України є гарантією допустимого збирання доказів.

\section{Jimepamypa}

1. Бем М. Отримання доступу до речей $\mathrm{i}$ документів у світлі практики ЄСПЛ. Інтернет-сторінка АО «ЮФ «Василь Кісіль і Партнери». URL: https://vkp.ua/publication/otrimannya-dostupu-dorechey-i-dokumentiv-u-svitli-praktiki-iespl (дата звернення: 26.08.2020).

2. Бірюков В.В. Криміналістичне документознавство. Київ : Паливода А.В. 2007. 331 с.

3. Вирок Андрушівського районного суду Житомирської області від 28.09.2017 року у справі 296/3990/16-к. URL: http://reyestr.court.gov.ua/ Review/69213571 (дата звернення: 26.08.2020).

4. Коваленко А.В. Особливості тактики огляду електронних документів під час досудового розслідування посягань на життя та здоров'я журналіста. Вicник Національної академії правових наук України : зб. наук. пр. / редкол.: О.В. Петришин та ін. Харків : Право. 2017. № 1 (88). С. 182-191.

5. Малахова О.В. До питання огляду сторонами кримінального провадження змісту інтернет-сторінок. 
Вісник кримінального судочинства. 2017. Вип № 2. C. $64-69$.

6. Ратнова А.В. Допустимість електронних документів у кримінальному провадженні на етапі збирання доказів (Admissibility of electronic documents in criminal proceedings at the stage of evidence collection). Sciences of Europe. 2019. Вип. 4 (№ 44). С. 37-42.

7. Ратнова А.В. Електронний документ та його місце у системі доказів у кримінальному провадженні. Науковий вісник Львівського державного університе ту внутрішніх справ. Серія юридична. 2018. Вип. 3 C. 231-241.

8. Ратнова. А.В. Використання роздруківки та скріншоту інтернет-сторінки під час доказування у кримінальному провадженні. Кримінальне процесу альне та криміналістичне забезпечення досудового розслідування : матеріали науково-практичного семінару (25 жовтня 2019 р.) / упор. Р.М. Шехавцов. Львів : ЛьвДУВС. 2019. С. 92-95.

9. Селезньов В.В. Основи ринкової економіки України : посібник. Київ : А.С.К. 2006. 688 с.

10. Ухвала Жовтневого районного суду м. Дніпропетровська від 26.06.2019 року у справі № 201/7375/19. URL: https://zakononline.com.ua/court-decisions/ show/82783231 (дата звернення: 26.08.2020).

11. Ухвала Колегії суддів судової палати з розгляду кримінальних справ Львівського апеляційного суду від 06 лютого 2019 року у справі № 461/485/17. URL: http://reyestr.court.gov.ua/Review/79744493 (дата звернення: 26.08.2020).

12. Ухвала Солом'янського районного суду м. Києва від 19.07.2019 року у справі № 760/16979/19. URL: http://reyestr.court.gov.ua/Review/84005340 (дата звернення: 26.08.2020).

13. Хижняк Є.С. Особливості огляду електронних документів під час розслідування кримінальних правопорушень. Держава та регіони. Серія: Право. 2017. № 4 (58). С. $80-85$.

\section{Анотація}

Ратнова A. В. Проведення огляду облікового запису користувача в соціальній мережі під час досудового розслідування кримінального провадження. - Стаття.

Інтернет забезпечує швидке зберігання та поширення великої кількості інформації між користувачами. Такі відомості можуть мати значення та підлягати доказуванню під час досудового розслідування кримінальних проваджень. Відсутність юридичної літератури, наукових розробок та інших знань з порядку проведення огляду відомостей, розміщених в Інтернеті, зокрема в облікових записах користувачів соцмереж, може створити труднощі під час його проведення або спричинити визнання його недопустимим, неналежним доказом.

Обліковий запис користувача дає можливість встановити коло осіб, з якими знайома особа, отримати фото особи, вивчити особисті якості, захоплення, дізнатись ставлення особи до певної події тощо. Ці відомості згодом можна використати для складення версій i плану розслідування, подальшого проведення слідчих (розшукових) дій, негласних слідчих (розшукових) дій, оперативно-розшукової діяльності.

Проведеним дослідженням встановлено, що залежно від ступеня доступу до облікового запису у соцмережі огляд може проводитись без відома особи - власника облікового запису із загальнодоступного ресурсу; з добровільним наданням доступу володільцем до персональної інформації облікового запису, листування тощо; отримання доступу до персональної інформації облікового запису, листування на підставі рішення суду.

Отримання мобільного телефону під час обшуку чи арешту не дає права правоохоронним органам на отримання змісту інформації, яка в ньому міститься. Тому слідчий може отримати згоду на огляд мобільного телефону, в тому числі відомостей і листування з облікового запису соцмережі за згодою власника або на підставі рішення суду про тимчасовий доступ до речей та документів. Дозвіл на отримання доступу до мобільних телефонів, мобільних терміналів систем (у разі неможливості копіювання, якщо доступ до них обмежується ïх власником, володільцем або утримувачем) можна отримати одразу під час звернення до суду з клопотанням про проведення обшуку, якщо у ньому зазначити та обIрунтувати таку необхідність.

За допомогою листування у соціальних мережах можна дізнатись про наявність домовленості на спільне скоєння злочину, розроблення плану його скоєння, приховування, мотив, мету і ставлення до правопорушення. Також листування може бути підтвердженням наявності конфлікту, вислову образ, погроз, примусу та ін. Під час огляду особистого листування користувача у соцмережі слід зазначати про добровільність надання облікового запису на огляд або наявність відповідної ухвали суду на огляд; інформацію про те, з якого пристрою здійснюється вхід у соціальну мережу, індивідуальні ознаки такого пристрою, спосіб входу у соціальну мережу - через браузер чи додаток, обліковий запис, з якого здійснено вхід, основні персональні дані, які зазначені у ньому, дата та час отримання повідомлень, їх зміст, обліковий запис, з якого надходили повідомлення, основні персональні дані цього облікового запису, додані ним раніше фотографії тощо.

Єдиною слідчою (розшуковою) дією, за допомогою якої можна провести огляд сторінки, є огляд. У статті акцентується увага на тому, що огляд слід проводити за участю спеціаліста, який може звернути увагу на важливі деталі та допоможе підготувати додатки до протоколу огляду, виготовити копію облікового запису. Запропоновано проведення огляду облікового запису користувача 3 проведенням безперервного відеозапису екрана через відповідну програму, функцію технічного пристрою та надалі його додавання до протоколу огляду у вигляді додатка.

Ключові слова: огляд, електронний документ, доказ, обліковий запис користувача соціальної мережі, електронне листування, Інтернет.

\section{Summary}

Ratnova $A$. $V$. Reviewing the user's account on the social network during the pre-trial investigation of criminal proceedings. - Article.

The Internet provides fast storage and distribution of a large amount of information among users. Such information may proof the pre-trial investigation of the criminal proceedings. Lack of legal literature, scientific researches and other knowledge on the procedure of reviewing information posted on the Internet, particularly check of the users accounts on social networks may lead to difficulties while conducting such check or lead to inadequate evidence.

A user account allows to set the social circle, get a photo of the person, learn personal qualities, hobbies, find out the attitude of a person to a particular event etc. This information can be used to compose versions, make a plan of investigation, to carry out investigative actions, operational and investigative measures. 
Such kind the user account review on the social network can be conducted without account owner permission; it may be conducted with an access to personal information and correspondence; an access to personal information or correspondence can be obtained on the basis of court decisions.

Receiving a mobile phone during a house-check or arrest does not entitle law enforcement agencies to obtain the content of the information contained therein. Therefore, the investigator may obtain consent to inspect the mobile phone, including information and correspondence from the social network account with the consent of the owner, or on the basis of a court decision on temporary access to stuff and documents. Permission to access mobile phones, mobile system terminals (in case of impossibility of copying, if access is restricted by the owner or holder) can be obtained immediately by applying to the court, while indicating and justifying such necessity.

With the help of correspondence on social networks, it is possible to find out the agreement on the joint commission of a crime, to develop a plan for its commission, concealment, motive, purpose and attitude to the offense. Correspondence can also be a confirmation of the conflict presence, expression of insults, threats, coercion, etc. When reviewing user's personal correspondence on the social network, the account is voluntarily submitted for the review, or a court decision for review is made; information on which device is used to log in to the social network, individual features of a device, method of logging in to the social network - through a browser or application, the account from which the login is made, basic personal data specified in it, date and time of receiving messages, their content, the account from which the messages were received, personal data of this account, photos added earlier, etc.

The only investigative (search) action by which account review can be done is a review. The article emphasizes that the review should be conducted with the help of a specialist who can pay attention to important details and help to prepare appendices for the protocol to be reviewed, make a copy of the account. It is proposed to review user's account with continuous video recording of the screen through the appropriate program, and adding it to the review protocol as an application after.

Key words: review, electronic document, proof, social network of the user's account, electronic correspondence, Internet. 